\title{
STUDI EKSPERIMEN PEMILIHAN BIOMASSA UNTUK MEMPRODUKSI GAS ASAP CAIR ( LIQUID SMOKE GASES ) SEBAGAI BAHAN PENGAWET
}

\author{
Sugeng Slamet \\ Fakultas Teknik, Program studi Teknik Mesin \\ Universitas Muria Kudus \\ Email: sugeng_hanun@yahoo.co.id \\ Taufiq Hidayat \\ Fakultas Teknik, Program studi Teknik Mesin \\ Universitas Muria Kudus \\ Email: ophiqhd@gmail.com
}

\begin{abstract}
ABSTRAK
Pengertian umum asap cair merupakan suatu hasil destilasi atau pengembunan dari uap hasil pembakaran tidak langsung maupun langsung dari bahan yang banyak mengandung karbon dan senyawasenyawa lain. Bahan baku yang banyak digunakan untuk membuat asap cair adalah kayu, bongkol kelapa sawit, ampas hasil penggergajian kayu, dan lain-lain. Pembuatan asap cair menggunakan metode pirolisis yaitu peruraian dengan bantuan panas tanpa adanya oksigen atau dengan jumlah oksigen yang terbatas. Biasanya terdapat tiga produk dalam proses pirolisis yakni: gas, pyrolisis oil, dan arang, yang mana proporsinya tergantung dari metode pirolisis, karakteristik biomassa dan parameter reaksi. Metode yang dilakukan diawali dengan melakukan rancang bangun unit pirolisator lengkap dengan perangkat kondensor dengan pipa tembaga tipe spiral untuk memproduksi gas asap cair dari bahan biomassa yang dipilih yaitu tempurung kelapa dan sampah organik. Metode Pirolisis yang merupakan proses reaksi penguraian senyawa-senyawa penyusun kayu keras menjadi beberapa senyawa organik melalui reaksi pembakaran kering pembakaran tanpa oksigen. Reaksi ini berlangsung pada reaktor pirolisator dengan variasi temperatur $150^{\circ} \mathrm{C}, 250^{\circ} \mathrm{C}$ dan $300^{\circ} \mathrm{C}$ selama 8 jam pembakaran. Asap hasil pembakaran dikondensasi dengan kondensor yang berupa pipa tembaga melingkar. Hasil dari proses pirolisis diperoleh tiga produk yaitu asap cair, tar, dan arang. Kondensasi dilakukan dengan pipa atau koil melingkar yang dipasang dalam bak pendingin. Air pendingin dapat berasal dari air hujan yang ditampung dalam bak penampungan. Hasil yang diperoleh dari penelitian ini adalah biomassa tempurung kelapa menghasilkan jumlah senyawa fenol lebih besar 30-33\%. Hal ini menunjukkan bahwa pada jenis biomassa ini lebih unggul dalam fungsi sebagai antioksidan, karena kaya akan kandungan senyawa fenol, sehingga lebih optimal dalam hal menghambat kerusakan pangan dengan cara mendonorkan hidrogen. Sedangkan biomassa cangkang kopi pada temperatur $150^{\circ} \mathrm{C}$ lebih banyak menghasilkan senyawa asam 93\%. Kandungan asam efektif dalam mematikan dan menghambat pertumbuhan mikroba pada produk makanan dengan cara senyawa asam itu menembus dinding sel mikroorganisme yang menyebabkan sel mikroorganisme mati peningkatan kapasitas hasil seiring dengan meningkatnya temperatur uap biomassa.
\end{abstract}

Kata kunci: Asap cair, pirolisis, kondensasi, pengawet alami, fenol,senyawa asam.

\begin{abstract}
General understanding of liquid smoke is a result of condensation of steam distillation or combustion products are directly or not directly from material that contains carbon and other compounds. The raw materials used to make liquid smoke is wood, palm oil hump, sawmill residue results, and others. Making liquid smoke using pyrolysis method is decomposition with the aid of heat in the absence of oxygen or with a limited amount of oxygen. Usually there are three products in the pyrolysis process: gas, pyrolisis oil, and charcoal, which is where the proportions depending on the method of pyrolysis, biomass characteristics and parameters of the reaction. Methods that begin with the design pirolisator unit complete with condenser device with spiral-type copper pipe gas to produce liquid smoke from biomass materials selected in coconut shell and organic waste. Pyrolysis method which is the process of decomposition reaction constituent compounds hardwood into some organic compounds by dry combustion reaction without oxygen combustion. This reaction takes place in the reactor with temperature variation pirolisator $150^{\circ} \mathrm{C}, 250^{\circ} \mathrm{C}$ and $300^{\circ} \mathrm{C}$ for 8 hours burning. The smoke of burning condensed by the condenser in the form of a circular copper pipe. The results obtained from the pyrolysis
\end{abstract}


process three products namely liquid smoke, tar, and charcoal. Condensation is done with a pipe or coiled coil mounted in a cooling bath. Cooling water can come from rain water collected in the tank.The results obtained from this study is coconut shell biomass yield greater amount of phenolic compounds 30$33 \%$. This indicates that the type of biomass is superior in function as an antioxidant, as rich in phenolic compounds, so that more optimal in terms of inhibiting the breakdown of food by way of donating hydrogen. While the biomass at a temperature of $150 \mathrm{oC}$ coffee shell produces more acid compounds 93\%. Acid content deadly and effective in inhibiting the growth of microbes in food products in a way that acidic compounds penetrate the cell walls of microorganisms that cause cell death microorganisms increased capacity results in with temperature steam biomass increased.

Keywords: Liquid smoke, pyrolysis, condensation, a natural preservative, phenol, acid compounds.

\section{PENDAHULUAN}

Limbah biomassa yang merupakan bahan organik yang banyak kita jumpai disekeliling kita. Biomassa tersebut belum dapat diambil manfaatnya secara ekonomi sebelum dilakukan proses lanjut/daur ulang. Limbah biomassa merupakan sumber energi dan bahan baku produk lainnya yang cukup besar potensinya untuk diolah lebih lanjut. Beberapa limbah biomassa yang potensial untuk bahan baku adalah tempurung kelapa, sampah organik, jerami, cangkang kopi, cangkang sawit. Hasil olahan dari limbah biomassa tersebut dapat digunakan untuk konversi energi, komposit material, bahan bakar briket, bahan pengawet berupa asap cair dan lainnya (.......).

Pengertian umum asap cair (liquid smoke) merupakan suatu hasil destilasi atau pengembunan dari uap hasil pembakaran tidak langsung maupun langsung dari bahan yang banyak mengandung karbon dan senyawa-senyawa lain (Kamulyan, B., 2008). Bahan baku yang banyak digunakan untuk membuat asap cair adalah tempurung kelapa, kayu, bongkol kelapa sawit, ampas hasil penggergajian kayu, dan biomass lainnya. Asap cair bisa juga berarti hasil pendinginan dan pencairan asap dari bahan biomass yang dibakar dalam tabung tertutup. Asap yang semula partikel padat didinginkan dan kemudian menjadi cair itu disebut dengan nama asap cair. Asap cair umumnya digunakan sebagai pengganti teknik pengasapan konvensional.

Pengasapan ikan atau daging dilakukan untuk tujuan pengawetan makanan. Disamping itu juga untuk meningkatkan cita rasa dari makanan itu sendiri. Pembuatan asap cair menggunakan metode pirolisis yaitu penguraian dengan bantuan panas tanpa adanya oksigen atau dengan jumlah oksigen yang terbatas ( Yuliwati dkk, 2011). Biasanya terdapat tiga produk dalam proses pirolisis yakni: gas, pyrolisis oil, dan arang, yang mana proporsinya tergantung dari metode pirolisis, karakteristik biomassa dan parameter reaksi. Alat pirolisis seperti ditunjukkan pada gambar 1.

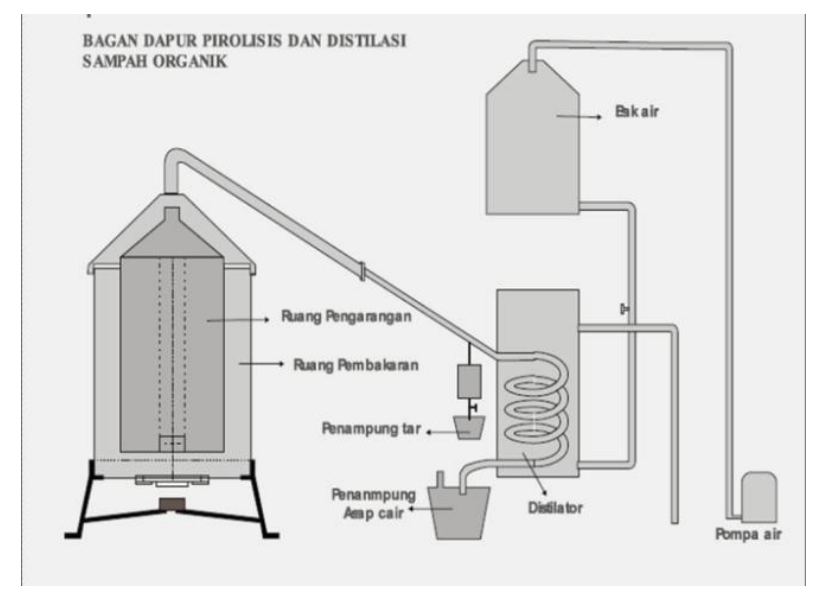

Gambar 1. Alat Pirolisis Asap Cair [1]

Asap hasil pembakaran dikondensasi dengan kondensor yang didalamnya terdapat pipa berupa koil melingkar yang dipasang dalam bak pendingin. Air pendingin dapat berasal dari air hujan yang ditampung dalam bak penampungan, air sumur, air sungai maupun PDAM. Adapun permasalahan dari biomassa sebagai rujukan dalam penelitian ini, didasarkan atas berbagai pertimbangan sebagai berikut :

1. Biomassa yang merupakan sumber energi dari bahan dasar organik yang belum banyak dimanfaatkan. Biomassa masih dipandang sebagai limbah atau sampah yang tidak memiliki nilai 
ekonomis, sehingga cenderung dibuang sembarangan. Padahal biomassa dapat ditingkatkan nilainya dengan mengolah menjadi pupuk organik, asap cair dan bahan bakar.

2. Diperlukan peralatan dan teknologi untuk dapat mengolah biomassa menjadi asap cair yaitu pirolisator. Teknologi ini dapat dibuat sesuai skala produksi dan biaya yang ada, sehingga masyarakat dapat melakukan proses pirolisis sebagai bagian dari kegiatan usaha. Proses pengoperasian dari unit pirolisator ini juga tidak sulit termasuk juga proses maintenance/perawatannya.

3. Temperatur optimal pada pirolisator yang mampu menghasilkan asap cair dalam jumlah yang besar, serta jenis biomassa yang menghasilkan senyawa sebagai bahan pengawet bahan pangan.

Sedangkan tujuan yang diharapkan dari pengolahan limbah biomassa adalah sebagai berikut :

1. Mendapatkan gas asap melalui teknologi pirolisis dengan cara mengolah bahan biomassa yang ada disekeliling kita.

2. Mengetahui senyawa yang terkandung dalam gas asap dari jenis biomassa yang dijadikan sampel dalam penelitian ini yaitu : tempurung kelapa dan cangkang kulit kopi.

3. Mengetahui pengaruh peningkatan temperatur pirolisator terhadap kapasitas gas asap yang dihasilkan serta kandungan dalam gas asap biomassa tersebut.

\section{METODOLOGI PENELITIAN}

Tahapan dalam penelitian ini meliputi :

a. Peralatan dan bahan yang digunakan dalam penelitian adalah :

1. Unit pirolisator yang sudah dilengkapi dengan pengukur temperatur dan tekanan.

2. Unit kondensor, dengan susunan pipa tipe koil/helical tube

3. Timbangan

4. Pompa air

5. Pipa distribusi gas asap

6. Alat penangkap tar

7. Alat uji : Simadzu GCMS-TQ 8030

8. Biomassa : tempurung kelapa dan cangkang kulit kopi

b. Data teknik mesin penghasil asap cair meliputi :

1. Alat pirolisator

- Pirolisator bekerja pada suhu $32^{\circ} \mathrm{C}-350^{\circ} \mathrm{C}$

- Tabung Pirolisis mampu menahan tekanan kerja 5,3 - 6 bar dengan temperatur maksimal $650^{\circ} \mathrm{C}$.

- Tabung pirolisis dilengkapi stop kran, pressure gauge, termometer, dan safety valve untuk keperluan analisa.

- Skala maksimal termometer $400^{\circ} \mathrm{C}$ dengan jenis termometer bimetal.

- Skala maksimal pressure gauge $10 \mathrm{Kg} / \mathrm{cm}^{2}$.

- Safety valve kompresor Shark ukuran 1,5 - 2 HP.

- Material tabung pirolisis baja tahan karat 201 (Stainless Steel 201) dengan tebal 1,8 mm.

2. Pipa distribusi uap

- Koefisien tahanan (K) pada pipa distibusi sebesar 11,342

- Jenis pipa penghubung yang digunakan adalah baja krom-nikel; diameter dalam = 19,05 $\mathrm{mm}$, diameter luar $=20,25 \mathrm{~mm}$ dan tebal pipa $=0,6 \mathrm{~mm}$

- Jenis aliran yang melalui pipa laminer.

- Kecepatan alir gas asap 1,516 m/s

- Panjang pipa penghubung pirolisator-kondensor adalah 1,52 meter.

3. Kondensor

- Tabung kondensor bahan stainless steel.

- Pipa kondensor menggunakan pipa tembaga dengan diameter $1 / 2$ inchi.

- Panjang total pipa kondensor $6 \mathrm{~m}$

Biomassa yang digunakan terdiri dari 2 macam, sebagaimana ditunjukkan pada gambar 2. Alat penghasil asap cair ditunjukkan pada gambar 3. 


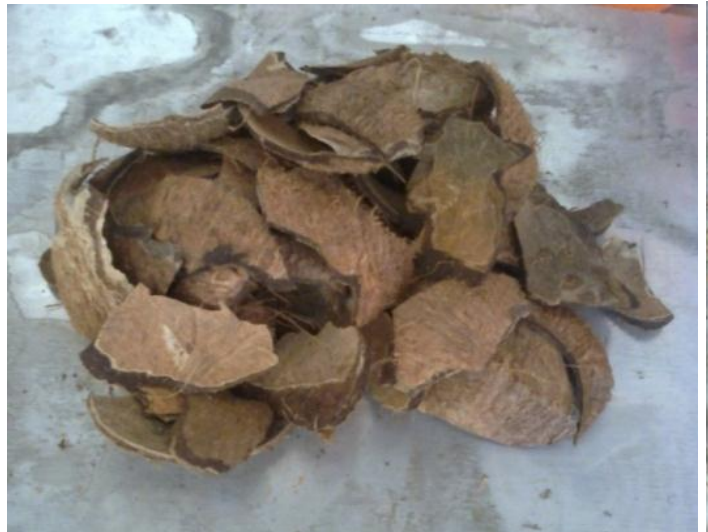

(a)

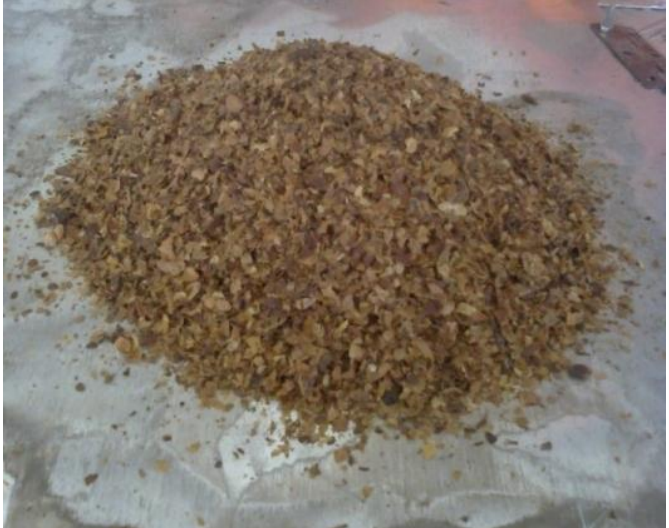

(b)

Gambar 2. Limbah biomassa (a) tempurung kelapa (b) cangkang kulit kopi

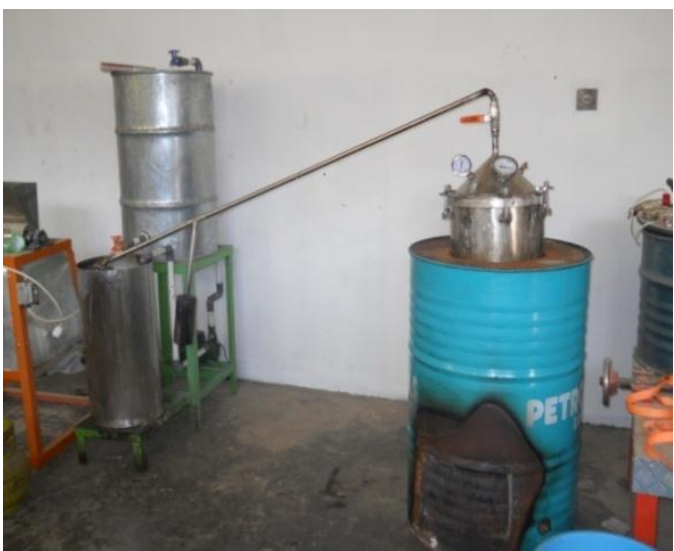

(a)

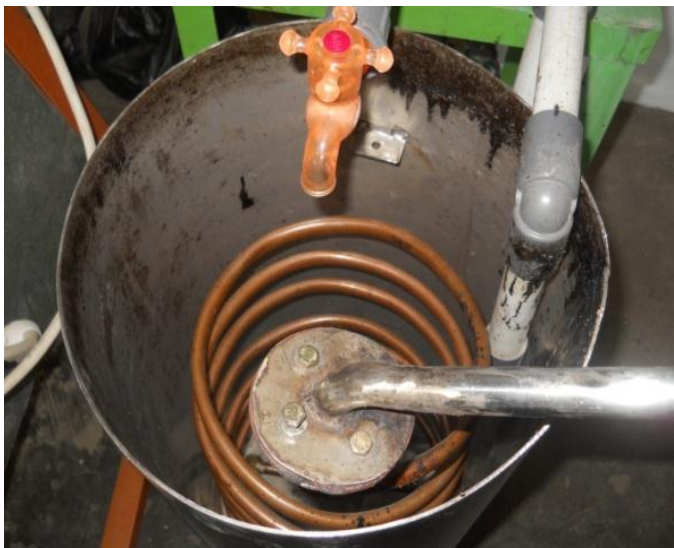

(b)

Gambar 3. Perangkat penghasil asap cair (a) pirolisator (b) kondensor

c. Proses pembuatan asap cair

1. Sebelum dimasukkan ke reaktor pirolisis, biomassa tempurung kelapa dibersihkan dari kotoran dan sabut yang tertinggal. Kemudian tempurung kelapa dipecah menjadi beberapa bagian agar luas permukaan pembakaran menjadi lebih luas sehingga proses dapat berjalan lebih cepat.

2. Selanjutnya dilakukan pengeringan dengan cara penjemuran, untuk mengurangi kadar air pada tempurung kelapa.

3. Kemudian dilanjutkan dengan metode Pirolisis yang merupakan proses reaksi penguraian senyawa-senyawa penyusun kayu keras menjadi beberapa senyawa organik melalui reaksi pembakaran kering pembakaran tanpa oksigen. Reaksi ini berlangsung pada reaktor pirolisator yang bekerja pada temperatur $150-300^{\circ} \mathrm{C}$ selama 8 jam pembakaran.

4. Asap hasil pembakaran dikondensasi dengan kondensor yang berupa koil melingkar. Hasil dari proses pirolisis diperoleh tiga produk yaitu asap cair, tar, dan arang. Kondensasi dilakukan dengan pipa tembaga berdiameter $10 \mathrm{~mm}$ yang dipasang dalam bak pendingin. Air pendingin menggunakan air sumur.

5. Asap hasil pembakaran biomassa dialirkan melalui pipa-pipa kecil atau tube dalam kondensor. Sedangkan air pendingin dialirkan di bagian luarnya atau didalam shell menggunakan sebuah pompa air. Parameter yang diukur adalah kapasitas hasil pirolisis asap cair. Hasil asap cair ditampung dalam sebuah bejana yang kemudian bisa di ketahui volumenya. Kapasitas hasil dihitung per satuan waktu.

6. Hal yang sama dilakukan pada biomassa cangkang kulit kopi.

Data yang sudah didapatkan, selanjutnya akan dianalisa untuk mengetahui sejauhmana unjuk kerja unit pirolisator penghasil gas asap cair terhadap bahan baku dari biomassa tempurung kelapa dan cangkang kulit kopi dengan variabel bebasnya adalah temperatur. Selanjutnya unjuk kerja unit pirolisator dapat ditentukan dengan melihat peningkatan kapasitas hasil dengan pendekatan empiris sebagai berikut : 
$\%=\frac{W_{2}-W_{1}}{W_{2}} \times 100 \%$

Keterangan :

$\mathrm{W}_{2}=$ berat awal $(\mathrm{kg}$, liter $)$

$\mathrm{W}_{1}=$ berat $(\mathrm{kg}$, liter $)$

Adapun tahapan yang dilakukan dalam penelitian ini sebagaimana ditunjukkan dalam diagram alir gambar 4.

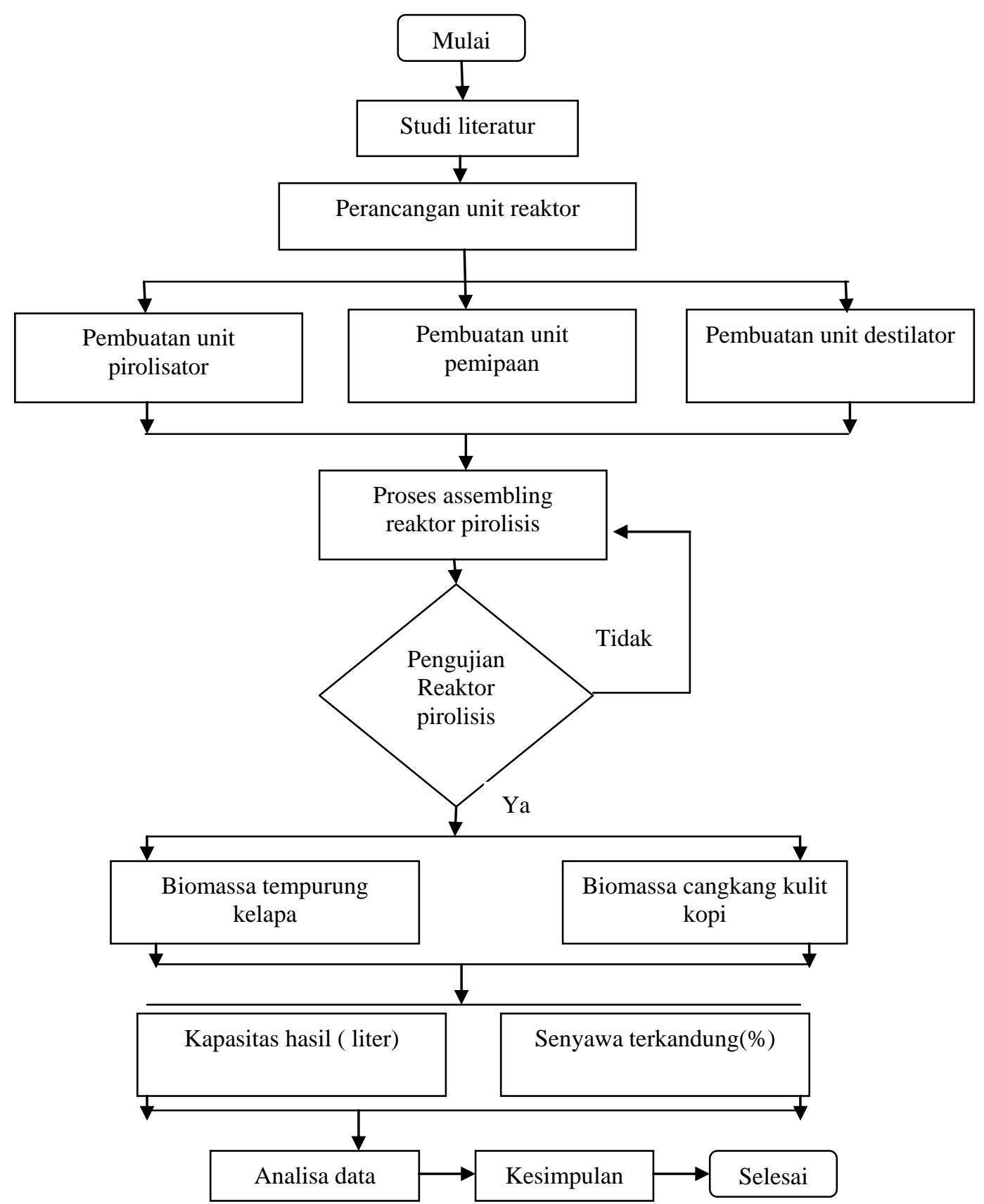

Gambar 4. Diagram alir penelitian

\section{HASIL DAN PEMBAHASAN}

Data yang diperoleh dari hasil pengujian pada 2 biomassa penghasil gas asap cair dengan menggunakan metode pirolisis diperoleh data ditampilan pada tabel 1 dan gambar 5 sebagai berikut: 
Tabel 1. Kapasitas hasil (liter) gas asap cair

Kapasitas Hasil asap cair terhadap temperatur pirolisis (ml)

\begin{tabular}{cccc} 
& $150^{\circ} \mathrm{C}$ & $250^{\circ} \mathrm{C}$ & $300^{\circ} \mathrm{C}$ \\
\hline \multirow{2}{*}{ Tempurung kelapa } & 728 & 1135 & 1305 \\
& 727 & 1133 & 1303 \\
& 724 & 1130 & 1300 \\
\hline Rerata & 726,33 & 1132,67 & 1302,67 \\
\hline \multirow{2}{*}{ Cangkang kulit } & 445 & 750 & 960 \\
kopi & 450 & 749 & 959 \\
& 456 & 748 & 869 \\
\hline rerata & 450,33 & 749 & 929,33 \\
\hline
\end{tabular}

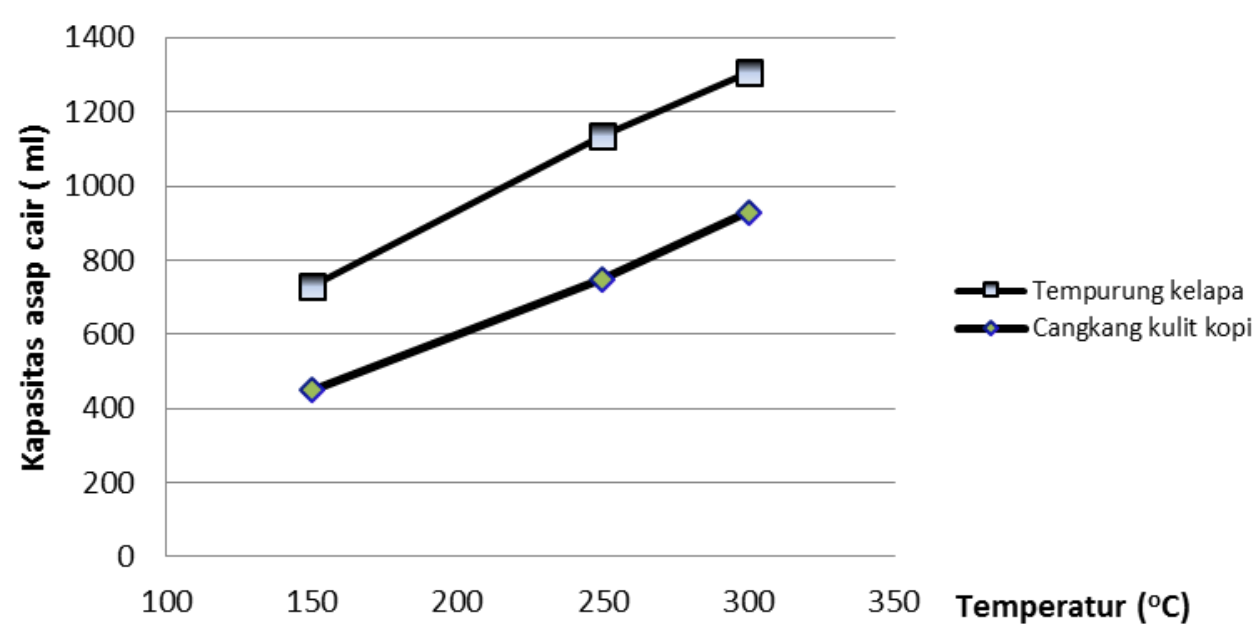

Gambar 5. Grafik kapasitas asap cair biomassa terhadap perlakukan temperatur

Tabel 2. Kandungan senyawa (\%) gas asap cair

\begin{tabular}{ccccc}
\hline \multirow{2}{*}{ Jenis Biomassa } & Temperatur operasi ${ }^{\circ} \mathrm{C}$ & \multicolumn{3}{c}{ Kandungan mayor senyawa dalam asap cair } \\
& & Fenol & Furan & Senyawa asam \\
\hline \multirow{2}{*}{$\begin{array}{c}\text { Tempurung } \\
\text { kelapa }\end{array}$} & 150 & 62,78 & 25,98 & 10,31 \\
& 250 & 67,19 & 20,94 & 10,89 \\
\hline \multirow{2}{C}{$\begin{array}{c}\text { Cangkang kulit } \\
\text { kopi }\end{array}$} & 300 & 72,56 & 15,86 & 11,05 \\
\hline & 150 & 5,14 & 0,94 & 93,08 \\
& 250 & 42,42 & - & 57,58 \\
& 300 & 50,86 & - & 48,67 \\
\hline
\end{tabular}


Tabel 2 tersebut diatas merupakan data kandungan yang dominan, diperoleh melalui pengujian chromatografi pada sampel sebanyak 100 gram asap cair dengan alat uji Simadzu GCMS-TQ 8030 di Laboratorium teknik kimia Universitas Diponegoro Semarang, gambar 6 dan 7 menunjukkan salah satu hasil pengujian chromatografi pada temperatur $150^{\circ} \mathrm{C}$.
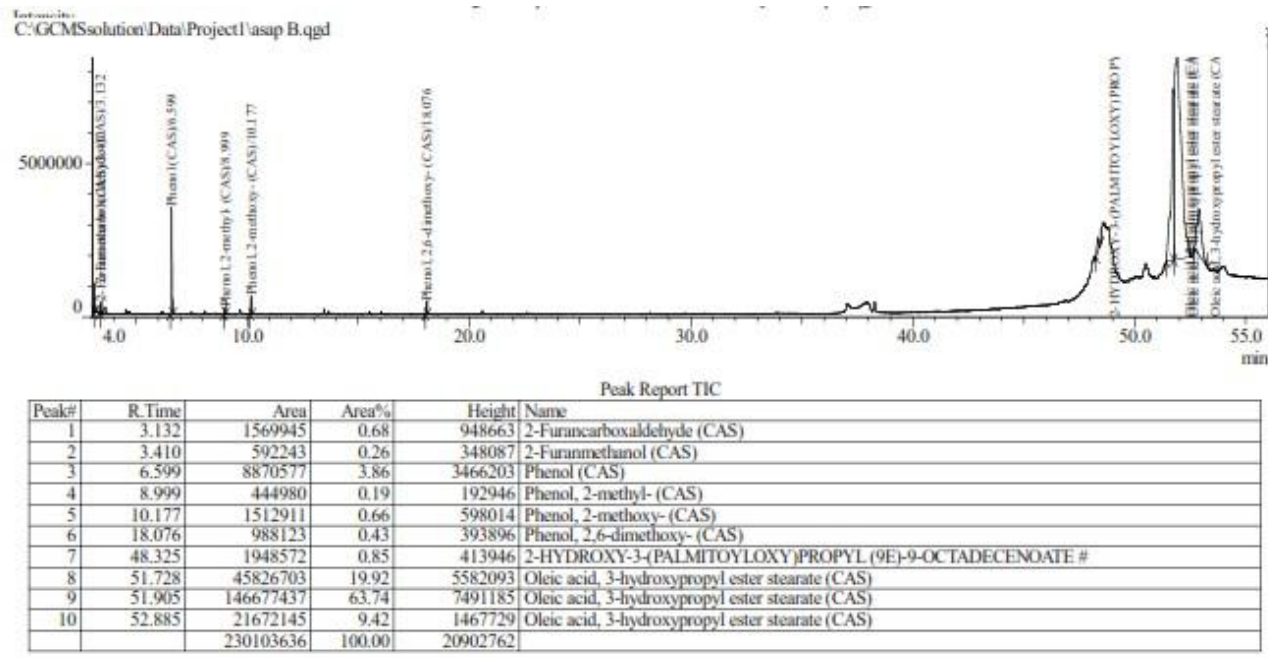

Gambar 6. Cromatogram asap cangkang kulit kopi temperatur $150^{\circ} \mathrm{C}$
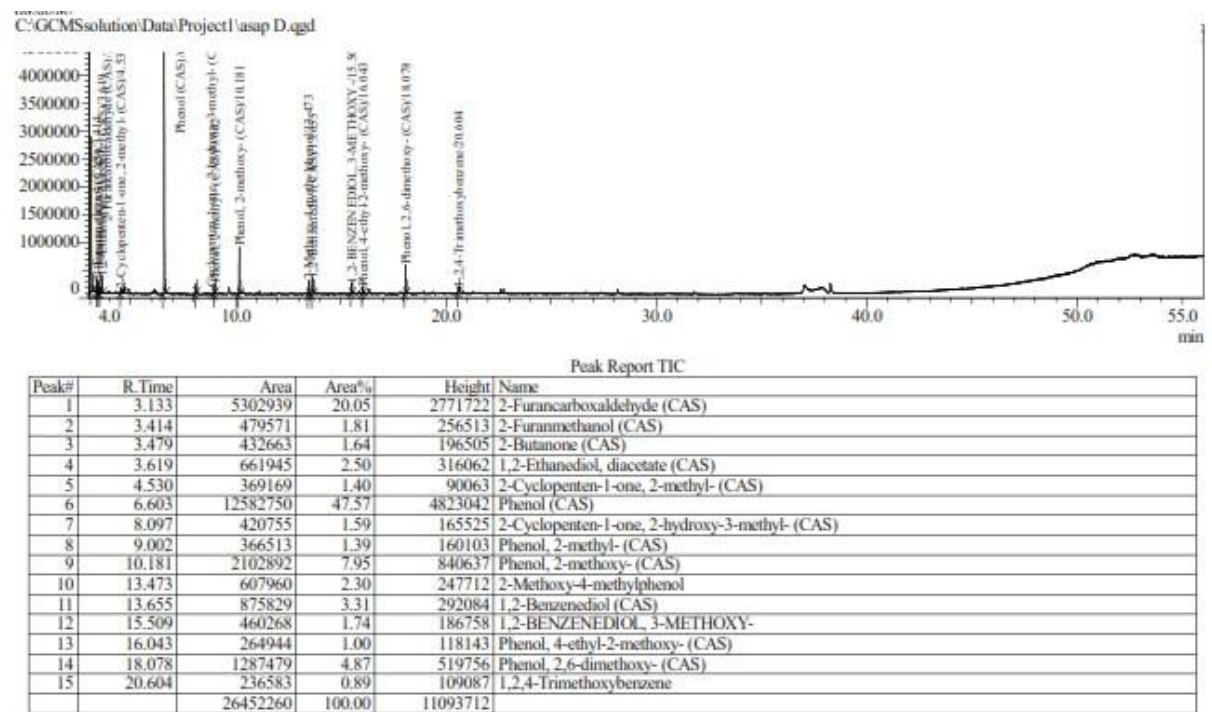

Gambar 7. Cromatogram asap tempurung kelapa temperatur $150^{\circ} \mathrm{C}$

Reaktor pirolisator sangat dipengaruhi oleh jenis biomassa, temperatur pembakaran serta tipe destilator yang berfungsi mengubah fase uap menjadi fase cair. Dari hasil penelitian yang dilakukan menunjukkan bahwa biomassa tempurung kelapa yang mempunyai struktur kayu keras pada temperatur yang sama menghasilkan senyawa fenol 30-33\% yang lebih banyak dibandingkan dengan biomassa cangkang kulit kopi. Sedangkan biomassa cangkang kopi pada temperatur $150^{\circ} \mathrm{C}$ lebih banyak menghasilkan senyawa asam 93\%. Senyawa asam ini menunjukkan perbandingan terbalik dengan variabel temperatur, dimana ketika temperatur gas asap dinaikkan senyawa asam menurun dan senyawa fenolnya meningkat. Kenaikan senyawa fenol yang sangat signifikan terjadi pada temperatur $250^{\circ} \mathrm{C}$ sebesar $85 \%$. Senyawa fenol mempunyai fungsi sebagai antioksidan sehingga lebih optimal dalam hal menghambat kerusakan pangan dengan cara mendonorkan hidrogen sebagai bahan pengawet. Sedangkan kandungan asam efektif dalam mematikan dan menghambat pertumbuhan mikroba pada produk makanan dengan cara senyawa asam itu menembus dinding sel mikroorganisme yang menyebabkan sel mikroorganisme mati. Tabel 3 menunjukkan terjadi peningkatan kapasitas hasil seiring dengan meningkatnya temperatur uap biomassa. 


\section{Tabel 3. Peningkatan kapasitas hasil}

\begin{tabular}{ccc}
\hline Jenis biomassa & \multicolumn{2}{c}{ Peningkatan Kapasitas Hasil (\%) } \\
& $150^{\circ} \mathrm{C}-250^{\circ} \mathrm{C}$ & $250^{\circ} \mathrm{C}-300^{\circ} \mathrm{C}$ \\
\hline Tempurung kelapa & 35,87 & 13,07 \\
Cangkang kulit kopi & 39,88 & 19,40 \\
\hline
\end{tabular}

\section{KESIMPULAN}

Pirolisator merupakan unit reaktor untuk memproduksi gas asap cair, dengan prinsip kerja utama adalah megubah fase gas asap yang dihasilkan dari pembakaran biomassa menjadi fase cair asap tersebut. Kesimpulan yang dapat diambil dari kegiatan penelitian ini adalah :

1. Jenis biomassa sangat mempengaruhi unjuk kerja pirolisator dimana biomassa tempurung kelapa menghasilkan kapasitas hasil $(\mathrm{ml})$ asap cair lebih banyak dibandingkan biomassa cangkang kulit kopi.

2. Unit pirolisator dapat bekerja sempurna, dimana senyawa kimia yang terkandung dalam biomassa dapat terurai sekaligus mampu menangkap senyawa tas pada asap yang sangat berbahaya bagi kesehatan manusia.

3. Kandungan senyawa kimia asap cair pada kedua jenis biomassa didominasi senyawa fenol, furan dan senyawa asam. Senyawa ini merupakan zat pengawet untuk bahan pangan maupun non pangan melalui proses lanjut.

\section{UCAPAN TERIMA KASIH}

1. Rektor Universitas Muria Kudus

2. Ka. Lemlit Universitas Muria Kudus

3. Tim inovasi dan kreatifitas teknologi mahasiswa teknik mesin Universitas Muria Kudus.

4. Laboratorium teknik mesin UMK dan Laboratorium kimia terpadu Undip Semarang.

\section{DAFTAR PUSTAKA}

[1] Hidayat, DJ., 2013. Pembuatan Asap Cair Dengan Metoda Pirolisis Sebagai Bahan Pengawet Makanan, IPB, Bogor.

[2] Kamulyan, B., 2008. Isolasi Bahan Bakar(Biofuels) dari Tar-asap cair hasil pirolisis tempurung kelapa, Tesis, FMIPA, Universitas Gadjah Mada, Yogyakarta.

[3] Yuliwati, E., Santoso, B., 2011. Studi Pendahuluan dan Pemilihan Bahan Alat Pembuat asap Cair dari Bahan Baku Tempurung Kelapa. Fakultas Teknik, Universitas Bina Darma. 